\title{
Students' Feedback towards Using Facebook in Learning Arabic Language
}

\author{
Nik Mohd Rahimi ${ }^{1}$, Nor Azhan ${ }^{2}$, Wan Normeza ${ }^{3} \&$ Harun Baharudin ${ }^{1}$ \\ ${ }^{1}$ Faculty of Education, Universiti Kebangsaan Malaysia, Malaysia \\ ${ }^{2}$ Faculty of Modern Languages and Communication, Selangor International Islamic University College, \\ Malaysia \\ ${ }^{3}$ Universiti Teknologi Malaysia, Kuala Lumpur Campus, Malaysia \\ Correspondence: Nik Mohd Rahimi, Faculty of Education, Universiti Kebangsaan Malaysia, 43600 UKM Bangi, \\ Selangor, Malaysia. Tel: 60-3-892-16241.E-mail: nik@ukm.edu.my; nikmrahimi@gmail.com
}

$\begin{array}{lc}\text { Received: August 26, } 2015 & \text { Accepted: September 15, } 2015 \text { Online Published: November 23, } 2015 \\ \text { doi:10.5539/ass.v11n28p170 } & \text { URL: http://dx.doi.org/10.5539/ass.v11n28p170 }\end{array}$

\begin{abstract}
This study aims to identify the student's feedback with regard to using Facebook in learning Arabic language as a foreign language. The study was conducted in a higher learning institution that offers Arabic language as a foreign language. This study involved 22 students as the participants of the study conducted via a Facebook group that was specially created for this purpose. The results indicated positive response from the participants who engaged on the account to improve their language skills. The participants were also motivated to use Facebook to communicate with each other in Arabic language even though they have some setbacks due to some limitations. The participants also pointed out that they prefer Video Application or Picture Apps in giving their comments in Arabic language. The participants also agreed that Facebook can enhance their acquisition of new vocabs during discussion and conversation. This study showed that Facebook can guide the participants in the concepts of collaborative learning in virtual world as an alternative to the face-to-face learning in classroom.
\end{abstract}

\section{Introduction}

The development of ICT throughout the world has impacted and changed the landscape of the education system. Although the pedagogy of language still focuses on face-to-face interactive teaching and learning in the classroom between teachers and students, it has now become more powerful with the introduction of interactive learning by using ICT. This includes learning process both inside, and outside the classroom. Language pedagogy in particular, through the years, has undergone many transformations with the advent of ICT, including interactive TV, internet and the latest, social media networks such as Facebook (Aydin, 2014).

In the early stage of establishment of social media network, a study conducted by Curtis (2001) reported that $43 \%$ of respondents see Facebook as a social networking site and not as a tool for academic work. At that time, social network was used for specific purposes, for instance, to be in a network of friendship, or to gain specific interests and knowledge (Arroyo, 2012). However, nowadays, the role of social networking sites has evolved into a more productive function in which it is now able to bridge the gap and develop relationships between the government and the people, between business companies and their consumers as well as academicians and students.

Social media networking was found to be able to promote collaborative learning, as students are able to interact by giving responses and receiving feedbacks in short or long sentences almost instantly. Aydin (2014) believed that social media networks like Facebook have the potential to become powerful social networking sites because of its reflective qualities, collaborative learning and mechanisms of peer feedback. However, the use of social networking sites for learning purposes has to be improved as the maiority of students still engaged on it for non-academic purposes or social interactions. Although this advancement is making a headwav in language learning, computer mediated communication can still promote real (Boticki, 2013) and natural communication in authentic contexts until the students become independent in their learning (Nordin, Hamzah, Yunus, \& Embi, 2010; Hargis, Cavanough, Kamali, \& Soto, 2014).

In pedagogy, the use of computer-mediated communication (CMC) in teaching and learning has received great attention from researchers and scholars to conduct experimental and identical research (Jeong-Bae, 2011). It has 
also been used to boost the response to the students' centered learning, collaborative role, online learning and mentoring (Hsu, 2012) and also share knowledge.

Several studies on social networking sites for language acquisition and its skills have been conducted. Gruba (2004) in his study discussed about the guidelines for managing online collaborative learning tasks in accordance with appropriate instructional design. Similarly, Arroyo (2012) found that social networking sites affect collaborative learning in order to improve motivation, learning in group. improve what was learned, reduce fear and make the process of problem solving better. Barrs (2012) paid attention to the promotion of social interaction on the social network beyond classroom. Barrs (2012) also analyzed the total of posting, replying and the interaction between the posts in terms of its form. Based on Barrs' study, there should be a further research on the applications in social networking that would motivate students to interact more. Thus, the concept of the classroom should be redefined to a new meaning (Damianakis, 2012) as the education field has changed and moved away to the front line of technologv. Therefore, this study aims to identify the student's feedback with regard to using Facebook in learning Arabic language as a foreign language.

\section{Method of the Study}

The researcher opened a new Facebook account for the purpose of this studv named "Hassin Lughatak" (mind your language) during the semester break. This study involved 22 students who registered and certified as a member of the "Hassin Lughatak" account. Friends from other higher institutions were not added and not allowed to participate in this group to maintain rigor and validity of the findings. The Facebook applications that were used in this study were videos, photos, links and notes. This study was carried out for four weeks, one week for each application, during the semester break. After completing the duration, the participants were given a set of questionnaire in the form of open-ended question on their perception towards Facebook applications used in this study. The participants were free to give their comments on each application. The length of the participants' comments was categorized into two categories: more than 10 words were considered as long sentence and less than 10 words were considered as short sentence.

\section{Findings}

Table 1 showed the number of comments and the number of students who participated in a discussion. The result showed that the highest number of comments was for Pictures Apps which hit 63 comments. The second highest number of comments recorded was for Links Apps which hit 62, followed by comments for Video Apps and Notes Apps.

However, result of the number of students' participation in discussion showed a slight difference compared to the number of comments, whereby the highest participation of students were on Pictures Apps and Video Apps, followed by Links Apps and finally the Notes Apps.

Table 1. Facebook application hit

\begin{tabular}{lllll}
\hline Application & No. of Comment & No. of Participation & Long sentence & Short sentence \\
\hline Video & 55 & 15 & 29 & 26 \\
Pictures & 63 & 16 & 36 & 27 \\
Links & 62 & 10 & 42 & 20 \\
Notes & 26 & 6 & 9 & 17 \\
\hline
\end{tabular}

The result indirectly indicated that the participants preferred using Pictures and Video Apps compared to other applications. This result was supported by the questionnaire result in Table 2. Table 2 showed that their preferred Applications in Facebook were Video Apps, followed by Pictures, Link and Note. It is interesting to note that despite being less preferred by participants, the Links Apps generated more Long Sentences compared to other apps.

Table 2. Participants' response on suitable applications in Facebook

\begin{tabular}{lllll}
\hline Application & Video & Picture & Link & Note \\
\hline Number of students & 10 & 8 & 3 & 1 \\
\hline
\end{tabular}


Table 3. Participants' response on language improvement through Facebook

\begin{tabular}{llll}
\hline Scale & Yes & No & Not sure \\
\hline Number of students & 18 & 4 & 0 \\
\hline
\end{tabular}

Table 4. Participants' response on the effectiveness of Facebook in improving writing skills

\begin{tabular}{llll}
\hline Scale & Yes & No & Not sure \\
\hline Number of students & 18 & 2 & 2 \\
\hline
\end{tabular}

Table 5. Participants' response on the effectiveness of Facebook for vocabulary enhancement

\begin{tabular}{llll}
\hline Scale & Yes & No & Not sure \\
\hline Number of students & 18 & 2 & 2 \\
\hline
\end{tabular}

Table 6. Response on the main problems in using Facebook

\begin{tabular}{|c|c|}
\hline & Students'Statement \\
\hline 6.1 & Students do not know how to pronounce new words. \\
\hline 6.2 & $\begin{array}{l}\text { In my opinion, the major problem in using Facebook is to practice language without using broken } \\
\text { language. }\end{array}$ \\
\hline 6.3 & $\begin{array}{l}\text { The first problem that arose was when students started using the short form in writing words; indirectly it } \\
\text { will become a habit for students to use short form. At the same time, students only know how to spell but } \\
\text { do not know how to correctly pronounce the words. }\end{array}$ \\
\hline 6.4 & $\begin{array}{l}\text { I feel uncomfortable in using Facebook because other students will observe my vocabulary, grammar and } \\
\text { language. This can lead to low self-esteem and motivation among students. }\end{array}$ \\
\hline 6.5 & $\begin{array}{l}\text { The major problem in using Facebook is not having much vocabulary to communicate and this leads to a } \\
\text { lack of self-confidence in communication. }\end{array}$ \\
\hline 6.6 & $\begin{array}{l}\text { The major problem is that we do not know whether the language we used in the posts we made is correct or } \\
\text { not. We also cannot correct our mistakes at that time. }\end{array}$ \\
\hline 6.7 & Sometimes, the internet access is very weak, so we cannot give our comment on the posting. \\
\hline 6.8 & $\begin{array}{l}\text { Many students or users who use broadband to access Facebook faced difficulties in getting fast internet } \\
\text { connection; so it is difficult to load videos, or even the Facebook page itself. It is also hard for them to post } \\
\text { comments. }\end{array}$ \\
\hline 6.9 & $\begin{array}{l}\text { In my opinion, the major problem in using Facebook to practice a foreign language is the availability of } \\
\text { internet access because not all the students have access to internet. }\end{array}$ \\
\hline
\end{tabular}

Table 7. Response on the benefit of group in Facebook

\section{Students' Statement}

7.1 Students can enrich their vocabulary and experience a different atmosphere by practicing language in a different medium.

There are many benefits in using Facebook group to practice a foreign language as students can learn new

7.2 vocabulary from other participants as well as being able to practice language at any time they want. There is also no time limit for them to comment on a post they like in Facebook.

There are many advantages and benefits. Firstly, students can share their knowledge and exchange opinion

7.3 through discussions and conversations as well as acquire new words. In addition, this Facebook group can encourage students to use foreign language more often.

7.4 In my opinion, Facebook groups can provide knowledge and latest information.

7.5 Facebook group offers me an attractive way of learning foreign language instead of going to the typical

7.5 classroom. Besides, I could learn more vocabulary and know other people's opinions on certain issues.

7.6 There is more time to practice foreign language as it is not only limited to the classroom.

7.7 We can practice foreign language to be more confident when we speak or write although we know that there must be mistakes made.

Table 3 showed that the maiority ( $81 \%$ ) of participants agreed that Facebook can be a channel to improve their learning of the Arabic language. The same percentage of participants also agreed that Facebook applications can 
help to improve their writing skills as well as vocabulary acquisition. These results were shown in Table 4 and Table 5. In the open-ended questionnaire, the participants gave their views on what they found to be the main problems and the benefit of a group in using Facebook to learn the Arabic language. The results were shown in Table 6 and Table 7.

\section{Discussion}

The findings showed that the majority of participants who engaged in the study via this Facebook group have motivation to improve their foreign language learning through comments and postings on Facebook. Table 4 showed that $81 \%$ of the participants agreed on the effectiveness of Facebook in improving their writing skills. Table 5 also showed that $81 \%$ of the participants agreed on the effectiveness of learning a foreign language on Facebook in acquiring new vocabulary. On the same ground, the participants gave the same responses on the benefit of Facebook group in Table 7. The participants' responses in item 7.1 and item 7.2 indicated that they learned new vocabulary through discussion and conversation in Facebook group.

Facebook was found to be effective as a channel for the participants to improve their foreign language learning, specifically their writing skills and new vocab acquisition because they have to write in Arabic language in order to post their comments on Facebook. They also have to read other participants' comments in Arabic language on the postings. This can improve their reading and writing skills in Arabic language.

While the participants were reading and posting comments, some of them will come across new vocabs and if they do not understand the new vocabulary, they can ask other people about their meaning. Consistently asking about the meaning of new vocabulary from one another is very beneficial for the participants as this will prolong the conversation between them. The more they converse, the more they will improve in terms of language acquisition.

Discussions and conversation in Facebook will promote the concept of collaborative learning (Burston, 2014). Usually, collaborative learning occurred in the face-to-face tutorials classroom, while with Facebook, collaborative learning occurs online without face-to-face interaction. To have face-to-face group interaction outside the classroom is not an easy task. Students must agree to a certain time and space to meet. They have to set the time and decide where to meet to have conversation and discussion. Having the facility to do so online, students can meet and discuss much easier outside the classroom as long as they have internet access.

Conversation and discussion are the most reliable learning methods in a foreign language classroom (Jarvis, 2013; Idham, Mahamod, Yunus, \& Rahimi, 2010). That is why all foreign language text books have a conversation part because conversation can help students practice foreign language among them in the classroom. The students hardly practice foreign language outside the classroom because not many people outside know the foreign language they are learning. Through Facebook, students can practice foreign language among them outside the classroom with ease. This was the participants' feedback in Table 7 item 7.2. They pointed out the many benefits of using Facebook group to practice foreign language whereby the students can learn new vocabulary from the others as well as practice language at any time they want to.

At the same time, the participants also gave their comments on the limitations of using Facebook in foreign language learning. As the study of Barrs (2012) have found, there are some limitations in using the social media as a medium of foreign language learning process. They discovered that learning can only be done in text form, and not in audio form. For some new words, the students must know how to pronounce them. Facebook cannot facilitate an audio form for them to hear the pronunciation of the new vocabulary. This was what the participants were worried about in Table 6 item 6.1, as they did not know how to pronounce new words.

Apart from that, the participants also pointed out that other limitations were the lack of access to Internet whether via broadband or Wi-Fi as one of the major problems in this trial period as well as weak internet signal "now you see it, now you don't" in remote areas. Video Applications cannot be downloaded in remote areas, and therefore the discussions will be cut off. These difficulties were shown in Table 6 item 6.7 and item 6.8 .

The problem that pertains specifically to learning Arabic language through Facebook is that it is very hard to find Arabic keyboard for some computers. The students must have Arabic keyboard in order to type Arabic language. On top of that, typing in Arabic language using keyboard for students learning Arabic as a second language is not as fast compared to Roman alphabets as they are not familiar with the order of Arabic alphabets on the keyboard.

These limitations should be considered in future research. This study is iust a beginning to explore the effectiveness of social media networking for collaborative learning in foreign language. especially in Arabic language. It is hoped that there will be a deeper study on the use of social media networking for all language skills and effective learning approach in the near future. 


\section{Conclusion}

Facebook is one of the social media platforms that can be manipulated as a pedagogy tool to enhance foreign language learning as long as it promotes conversations and discussions in foreign language. However, in order to make it more effective, the Facebook administrator should play a bigger role to activate two-way communication in Facebook. Reflection and correction in terms of grammar and semantics from the administrator can guide students to understand the language and use it verv well. Facebook applications in this study indicate that collaborative learning which was first introduced in the classroom can now be implemented in the virtual world with more extensive use and more content offered.

\section{References}

Arroyo, C. G. (2012). On-Line Social Network: Innovative Ways towards the Boost of Collaborative Language Learning (4th ed.). International Conference "ICT for Language Learning".

Aydin, S. (2014). Foreign language learners' instruction with their teacher on Facebook. System, 42, 155-163. http://dx.doi.org/10.1016/j.system.2013.12.001

Barrs, K. (2012). Fostering Computer-Mediated L2 Interaction beyond the Classroom. Language Learning \& Technology, 16(1), 10-25.

Boticki, I., Barisic, A., Martin, S., \& Drljevic, N. (2013). Teaching and learning computer science sorting algorithms with mobile device: A case study. Computer Applications in Engineering Education, 21(S1), E441-E450. http://dx.doi.org/10.1002/cae.21561

Burston, J. (2014). Twenty years of MALL project implementation: A meta-analysis of learning outcomes. First view article (Recall), 1-17.

Curtis, D. D., \& Lawson, M. J. (2001). Exlporing collabotaive online learning. Journal of Asynchronous Learning Networks, 5(1), 21-34.

Damianaki, T., \& Woodford, M. (2012). Qualitative research with small connected communities: Generating new knowledge while upholding research ethics. Qualitative Health Research, 22(5), 708-718. http://dx.doi.org/ $10.1177 / 1049732311431444$

Gruba, P. (2004). Designing Tasks for Online Collaborative Language Learning. Prospect, 19(2), 65-79.

Hargis, J., Cavanough, C., Kamali, T., \& Soto, M. (2104). A federal higher education iPad mobile learning inniative: Triangulation of data to determine early effectiveness. Innovative Higher Education, 39(1), 45-57. http://dx.doi.org/10.1007/s10755-013-9259-y

Hsu, L. (2012). English as a foreign language learners' perception of mobile assisted language learning: A cross national study. Computer Assisted Language Learning, 1-17.

Idham, M., Mahamod, Z., Yunus, M. D., \& Rahimi, N. M. (2010). Profil kecerdasan emosi guru pelatih bahasa mengikut tahun pengajian. GEMA: Online Journal of Language Studies, 10(2), 57-75.

Jarvis, H., \& Archileos, M. (2013). From computer assisted language learning to mobile assisted language learning. TESL-EJ, 16(4), 1-18.

Jeong-Bae, S. (2011). On The Internet: The Elektronic Journal for English as a Second Language. TESL-EJ, 15(1), 23-31.

Nordin, N. M., Hamzah, M. M. I., Yunus, M. M., \& Embi, M. A. (2010). The Mobile Learning Environment for the In-Service School Administrators. Procedia-Social and Behavioral Sciences, 7, 671-679. http://dx.doi. org/10.1016/j.sbspro.2010.10.091

\section{Copyrights}

Copyright for this article is retained by the author(s), with first publication rights granted to the journal.

This is an open-access article distributed under the terms and conditions of the Creative Commons Attribution license (http://creativecommons.org/licenses/by/3.0/). 